\title{
ANALISIS SISTEM PEMUNGUTAN, PEMBAYARAN, PENCATATAN DAN PELAPORAN PAJAK MINERAL BUKAN LOGAM DAN BATUAN PADA BADAN PENGELOLAAN KEUANGAN DAN ASET DAERAH KABUPATEN PULAU MOROTAI
}

\author{
Yosceline Mahino $^{1}$, Herman Karamoy ${ }^{2}$, Rudy J. Pusung ${ }^{3}$ \\ 1,2,3 Jurusan Akuntansi, Fakultas Ekonomi dan Bisnis, Universitas Sam Ratulangi, Jl. Kampus Bahu, Manado, \\ 95115, Indonesia
}

Email : yoscelinem89@gmail.com

\begin{abstract}
One of the efforts made in national development is the implementation of autonomy area. With regional autonomy, an autonomous region must be able to take care of and arrange the financing of the area itself. In order to implement the sector policy which plays an important role in regional financing is local revenue. Original regional income that sourced from tax revenue, levies and other legitimate regional revenues. Local Tax is one source of local revenue potentials that can be developed throught local tax revenues. Morotai Island Regency is one of autonomous district that has large potential resources, one of which is non-metallic minerals and rocks tax, but have not been managed effectively. The purpose of this study is to analyze whether the collection system, payment, recording and reporting of Non Mettalic mineral and Rocks tax already in accordance with Undang-Undang No 28 Tahun 2009 and Peraturan Pemerintah Nomor 55 Tahun 2016. The analytical method used is descriptive method. Based on the results of the study, it can be concluded that collection system, payment, recording and reporting of Non Mettalic mineral and Rocks tax is already appropriate with Undang-Undang No 28 Tahun 2009 and Peraturan Pemerintah Nomor 55 Tahun 2016 but in BPKAD still not a Standar Operation Procedur (SOP) for tax revenue. Internal Control for Non Metallic Mineral and Rocks tax using analysis COSO are sufficient only to needan increase in the risk assessment component.
\end{abstract}

Keywords: Non Mettalic Mineral and Rocks Tax, Collections System, Payment, Recording, Reporting, Internal Control

\section{PENDAHULUAN}

Kabupaten Pulau Morotai merupakan salah satu kabupaten otonom yang ada di Indonesia. Kabupaten Pulau Morotai dimekarkan dari kabupaten induknya yaitu Kabupaten Halmahera Utara oleh Menteri dalam Negeri Indonesia pada 29 oktober 2008 berdasarkan Undang-Undang Nomor 53 Tahun 2008 tentang Pembentukan Kabupaten Pulau Morotai. Sebagai kabupaten yang baru di Indonesia dengan pemberlakuan otonomi daerah, mengharuskan kabupaten ini untu mampu mendanai kebutuhan daerahnya. Sebagai salah satu alternatif dalam mendanai kebutuhannya yaitu dengan meningkatkan Pendapatan Asli Daerah (PAD) melalui pemungutan dan penerimaan Pajak Mineral Bukan Logam dan Batuan.

Badan pengelolaan Keuangan dan Aset daerah (BPKAD) Kabupaten Pulau Morotai didirikan sebagai penunjang pemerintahan daerah dalam penyusunan hingga pelaksanaan kebijakan daerah bidang keuangan dan aset daerah sesuai dengan perintah kepala daerah. BPKAD Kabupaten Pulau Morotai khususnya bidang pendapatan dan pajak yang melakukan pengawasan sistem pemungutan, pembayaran, pencatatan serta pelaporan Pajak Mineral Bukan Logam dan Batuan. Sumber-sumber kekayaan yang berlimpah terutama dalam bidang mineral dan bebatuan di Pulau Morotai dilihat sangat baik. Ada 8 jenis pajak daerah yang ditagih atau dipungut oleh Perintah Kabupaten Pulau Morotai. 
Besarnya potensi yang dimiliki oleh Kabupaten Pulau Morotai dilihat dari realisasi penerimaannya yang memberikan kontribusi yang cukup baik bagi pendapatan asli daerah, namun pencapaian penerimaannya setiap tahun belum sesuai antara target dan realisasi maka peneliti ingin melakukan penelitian yang berjudul "Analisis Sistem Pemungutan, Pembayaran, Pencatatan, dan Pelaporan Pajak Mineral Bukan Logam Dan Batuan Pada Badan Pengelolaan Keuangan Dan Aset Daerah". Penelitian ini bertujuan untuk menganalisis Sistem Pemungutan, Pembayaran, Pencatatan dan Pelaporan Pajak Mineral Bukan Logam dan Batuan yang ada di BPKAD Kabupaten Pulau Morotai apakah sudah dijalankan sesuai dengan Undang-Undang No. 28 Tahun 2009 dan Peraturan Pemerintah No. 55 tahun 2016 tentang Ketentuan Umum dan Tata Cara Pemungutan Pajak Daerah, serta menganalisis pengendalian internal yang dilakukan oleh BPKAD Kabupaten Pulau Morotai dalam penerimaan pajak .

\section{TINJAUAN PUSTAKA}

Pengertian Akuntansi. Pengertian akuntansi dapat berbeda-beda tergantung dari sudut pandang sesorang, namun pada dasarnya pengertian akuntansi selalu menekankan pada kegunaan akuntansi sebagai keputusan ekonomi. Akuntansi itu sendiri dapat dikatakan suatu ilmu atau seni yang meliputi proses pengidentifikasian, pencatatan, penggolongan, dan pengkhtisaran data yang bersifat keuangan dalam suatu perusahaan atau organisasi untuk mendapatkan informasi kemudian digunakan sebagai dasar dalam pengambilan keputusan ekonomi. Harahap (2013) menyatakan definisi akuntansi adalah suatu kegiatan jasa.

Akuntansi Pajak. Akuntansi pajak adalah pembuatan laporan keuangan fiskal sesuai ketentuan Undang-Undang Perpajakan yang meliputi proses pencatatan, penggolongan dan pengikhtisaran transaksi keuangan berkaitan dengan kewajiban perpajakan, hal ini dibuat karena adanya perbedaan antara akuntansi komersil dan akuntansi perpajakan.

Prinsip Akuntansi Pajak. Menurut Muljono (2018) prinsip akuntansi perpajakan yaitu Kesatuan Akuntansi, Kesinambungan, harga Pertukaran yang Objektif, Konsistensi dan Konservatif.

Fungsi Akuntansi Pajak. Menurut Muljono (2018) akuntansi perpajakan memiliki fungsi yaitu mengolah data kuantitatif sehingga menyajikan laporan keuangan yang memuat perhitungan perpajakan dan kemudian akan digunakan sebagai pertimbangan dalam pengambilan keputusan.

\section{Konsep Pajak}

Pengertian Pajak. Pajak adalah salah satu sumber pendapatan terbesar Negara Indonesia. Menurut Tampubolon (2016:14) pengertian pajak adalah iuran rakyat kepada negara bersifat memaksa dengan tidak mendapat balasan secara langsung.

Tujuan dan Fungsi Pajak. Tujuan diberlakukannya pajak yaitu untuk mencapai kondisi peningkatan ekonomi suatu negara; membatasi konsumsi; mendorong tabungan dan menanamkan modal; mentransfer sumber dari tangan rakyat ke pemerintah sehingga memungkinkan adanya investasi pemerintah; memodivikasi pola investasi; mengurangi ketimpangan ekonomi; dan memobalisasi surplus ekonomi. Fungsi pajak terbagi menjadi 2 yaitu Fungsi Anggaran (budgetair) dan Fungsi Mengatur (Mardiasmo 2016 : 4).

Pengelompokan Pajak. Pengelompokan pajak menurut Mardiasmo (2016: 7) terbagi menjadi 3 yaitu:

1. Menurut Golongannya. Menurut golongannya pajak digolongkan dalam 2 golongan yakni pajak langsung dan pajak tidak langsung.

2. Menurut Sifatnya. Menurut sifatnya pajak diuraikan dalam dua sifat yaitu pajak subjektif dan pajak objektif.

3. Menurut Lembaga Pemungutannya, pajak terbagi atas pajak pusat dan pajak daerah. 
Tata Cara Pemungutan Pajak. Resmi (2012 : 8) menyatakan bahwa tata cara pemungutan pajak terdiri dari:

1. Stelsel Pajak yaitu Stelsel Nyata (Rill), Stelsel Anggapan (fiktif) dan Stelsel campuran.

2. Asas Pemungutan Pajak yang terdiri atas tiga asas antara lain Asas Domisili, Asas Sumber dan Asas kebangsaan.

3. Sistem Pemungutan yaitu Officiacl assessment System, Self Assessment System dan Withholding System.

Pajak Daerah. Suatu daerah memiliki pajak yang dipungut serta dikelola oleh pemrintah daerah itu sendiri. Pajak yang diberlakukan atau dipungut oleh suatu daerah disebut sebagai Pajak Daerah. Pajak daerah pada dasarnya merupakan pembayaran yang diberikan oleh wajib pajak baik orang pribadi maupun badan sebagai subjek pajak yang dapat bersifat dipaksakan namun tanpa adanya timbal balik secara langsung.

Pajak Mineral Bukan Logam dan Batuan. Berdasarkan Peraturan Daerah Kabupaten Pulau Morotai No 08 Tahun 2011 tentang Pajak Mineral Bukan Logam dan Batuan menjelaskan bahwa pajak mineral bukan logam dan batuan merupakan pajak atas kegiatan pengambilan mineral bukan logam dan batuan, baik dari sumber alam di dalam dan/atau permukaan bumi.

Objek Pajak Mineral Bukan Logam dan Batuan. Berdasarkan PERDA Kabupaten Pulau Morotai Nomor 08 Tahun 2011 tentang Pajak Mineral Bukan Logam dan Batuan, dipungut pajak atas kegiatan pengambilan Mineral Bukan Logam. Objek Pajak adalah kegiatan pengambilan mineral bukan logam dan batuan meliputi 38 jenis mineral maupun batuan antara lain : Abses ; batu tulis; batu setengah permata; batu kapur; batu apung; batu permata; bentonit; dolomit; feldspar; garam batu (halite); dll. Orang pribadi atau badan yang dapat mengambil Mineral Bukan Logam dan Batuan disebut sebagai subjek pajak. Wajib Pajak Mineral Bukan logam dan Batuan adalah orang pribadi atau badan yang mengambil Mineral Bukan Logam dan Batuan.

Tarif Pajak Mineral Bukan Logam dan Batuan. Tarif pajak mineral bukan logam dan batuan ditetapkan sebesar 10\% (sepuluh persen) dari dasar pengenaan pajak. Tarif pajak tersebut disesuaikan deng Keputusan Bupati Pulau Morotai Nomor 970/115/PM/2018.

Tata Cara Pemungutan dan Penghitungan Pajak. Berdasarkan Peraturan Daerah Kabupaten Pulau Morotai No. 8 Tahun 2011 menyatakan tata cara pemungutan pajaknya yakni:

1. Pemungutan pajak dilarang dibongkarkan.

2. Wajib pajak menghitung, memperhitungkan dan menyetorkan pajak terutang dengan menggunakan SPTPD.

3. Pajak yang terutang dipungut di wilayah daerah tempat pengambilan mineral bukan logam dan batuan.

4. Besarnya pokok pajak yang terutang dihitung dengan cara mengalikan tarif pajak dengan dasar pengenaan pajak.

Tata Cara Pembayaran dan Penagihan Pajak Mineral Bukan Logam dan Batuan

1. Pembayaran pajak dilakukan di kas daerah atau tempat lain yang ditunjuk oleh bupati paling lambat 15 (lima belas) hari setelah berakhirnya masa pajak.

2. Pembayaran pajak yang tekah dihitung harus dibayarkan ke Kas Daerah paling lambat satu hari atau sesuai dengan keputusan bupati.

3. Pajak mineral bukan logam dan batuan dibayarkan dengan Surat Setoran Pajak daerah (SSPD).

4. Pajak yang terutang haruslah dibayarkan secara lunas.

5. Pembayaran pajak dapat diangsur dalam jangka waktu yang ditentukan oleh kepala daerah atau bupati dengan memenuhi persyaratan yang ada.

6. Angsuran untuk pajak yang kurang bayar atau belum dibayarkan dilaksanakan secara berkala dengan bunga $2 \%$ (dua persen) dari jumlah pajak tersebut. 
7. Penundaan untuk pembayaran pajak dapat diberikan berdasarkan keputusan bupati, sampai batas waktu tertentu apabila wajib pajak telah menyelesaikan pemenuhan persyaratan yang ditetapkan dengan dikenakan bunga $2 \%$ (dua pesen) sebulan dari jumlah pajak yang belum atau kurang dibayar.

Pengendalian Internal. Pengendalian internal control menurut COSO dapat dipahami sebagai prosedur dalam hal ini melibatkan dewam komisaris, manajemen serta personil lainnya melalui kegiatan operasi suatu badan usaha atau organisasi dan menjadi bagian integral dari kegiatan manajemen dasar. Pengendalian internal hanya dapat menyediakan keyakinan memadai, bukan keinginan mutlak.

Penelitian Terdahulu. Ada beberapa penelitian terdahulu yang penulis jadikan sebagai bahan pertimbangan pada saat melakukan penelitian di Badan Pengelolaan Keuangan (BPKAD) Kabupaten Pulau Morotai. Penelitian yang dilakukan oleh Sidik (2016) dengan judul Sistem Pemungutan Pajak Mineral Bukan Logam d.an Batuan (MINERBA) Pada Dinas Pendapatan Daerah Kabupaten Sekadau. Tujuan dari penelitian tersebut yaitu untuk mengetahuan sistem pemungutan Pajak Mineral Bukan Logam dan Batuan (MINERBA) yang diterapkan di Dinas Pendapatan Daerah Kabupaten Sekadau. Hasil penelitian menunjukkan sistem pemungutan untuk MINERBA di Kabupaten Sekadau masih belum dilaksanakan secara optimal sehingga untuk pendapatan MINERBA sendiri masih belum terkontrol dengan baik. Tesalonika (2016) dengan judul Analisis Potensi dan Efektivitas Penerimaan dan Pemungutan Pajak Mineral Bukan Logam dan Batuan Sebagai Sumber Pendapatan Asli Daerah (PAD) di Kabupaten Minahasa Utara. tujuan penelitiannya yaitu untuk mengetahui potensi dan efektivitas penerimaan maupun pemungutan pajak mineral bukan logam dan batuan sebagai sumber pendapatan asli daerah di minahasa utara tahun 2011-2015. Hasil penelitian menunjukkan Tingkat efektivitas penerimaan pajak mineral bukan logam dan batuan tahun 2011-2015 dikatakan sangat efektif dengan pencapaian presentase lebih dari $100 \%$.

\section{METODE PENELITIAN}

Jenis Penelitian. Jenis penelitian yang digunakan pada penelitian ini adalah penelitian kualitatif. Penelitian kualitatif merupakan penelitian sosial yang menggunakan informasi-informasi terkait dalam menginterpretasikan hasil. Pada penelitian ini penulis akan menganalisis system pemungutan, pembayaran, pencatatan dan pelaporan pajak mineral bukan logam dan batuan pada BPKAD Kabupaten Pulau Morotai.

Tempat dan Waktu Penelitian. Penelitian dilaksanakan pada Kantor Badan Pengelolaan Keuangan dan Aset Daerah Kabupaten Pulau Morotai. Jln. Pemancar TVRI Tanjung Dehegila, Desa Juanga, Kecamatan Morotai Selatan, Maluku Utara. Waktu penelitian dilaksanakan selama bulan Juni tahun 2018.

Jenis Data. Jenis data yang ada pada penelitian ini, yaitu:

1. Data Kualitatif. Data kualitatif dalam penelitian ini adalah data yang diperoleh dari hasil wawancara dengan bendahara penerimaan pajak di BPKAD Kabupaten Pulau Morotai berupa pertanyaan seputar pelaksanaan pemungutan, perhitungan, penyetoran serta pelaporan Pajak Mineral Bukan Logam dan Batuan.

2. Data Kuantitatif. Data kuantitatif dalam penelitian ini adalah SKPD, bukti pembayaran pajak bagan organisasi, dan profil instansi.

Sumber Data. Sumber data pada penelitian ini, yaitu:

1. Data Primer. Data primer dalam penelitian ini adalah data yang diperoleh dari hasil wawancara dengan bagian pendapatan dan pajak mengenai Pajak Mineral Bukan Logam dan Batuan seperti Objek pemungutan, tarif, prosedur pemungutan, prosedur pembayaran dan juga pencatatan serta pelaporannya di BPKAD Kabupaten Pulau Morotai. 
2. Data Sekunder. Data sekunder dalam penelitian ini adalah data yang diperoleh dari dokumen - dokumen BPKAD berupa struktur organisasi, dan profil instansi, dasar penetapan harga mpatokan penjualan, SKPD serta bukti pembayaran pajak.

Metode Pengumpulan data. Metode pengumpulan data dalam penelitian ini adalah studi dokumentasi, dan wawancara.

Metode dan Proses Analisis. Metode analisis yang digunakan dalam penelitian adalah metode analisis deskriptif. Adapun langkah - langkah untuk menganalisis data yang dilakukan oleh peneliti adalah sebagai berikut:

1. Menganalisis sistem pemungutan dan penghitungan pajak mineral bukan logam dan batuan pada BPKAD Kabupaten Pulau Morotai untuk melihat kesesuaian sistem pemungutan dan penghitungan tersebut apakah sudah sesuai dengan Undang-Undang No 28 Tahun 2009 dan Peraturan Pemerintah No 55 Tahun 2016.

2. Melakukan analisis sistem pembayaran dan penagigah pajak mineral bukan logam dan batuan pada BPKAD Kabupaten Pulau Morotai apakah sesuai dengan Undang-Undang No 28 Tahun 2009.

3. Melakukan analisis system pencatatan dan pelaporan pajak mineral bukan logam dan batuan pada BPKAD Kabupaten Pulau Morotai.

4. Melakukan analisis system pengendalian internal dengan pendekatan analisis COSO pada BPKAD.

\section{HASIL ANALISIS DAN PEMBAHASAN}

\subsection{Hasil Analisis}

Sistem dan Tata Cara Pemungutan Pajak Mineral Bukan Logam dan Batuan.

Sistem pemungutan yang digunakan oleh Badan Pengelolaan Keuangan Dan Aset Daerah Kabupaten Pulau Morotai untuk pajak mineral bukan Logam dan batuan sendiri yaitu Self Assesstment System. Self Assesstment System merupakan sistem pemungutan yang memberikan kepercayaan dan kewenangan bagi wajib pajak untuk menghitung dan membayar sendiri pajaknya berdasarkan peraturan yang berlaku. Objek yang di pungut oleh BPKAD Pulau Morotai ada 6 jenis, yaitu: Batu Kepala; Batu Belah; Kerikil; Pasir; Sirtu; Timbunan Pilihan. Tata cara pemungutan yang ada di BPKAD yaitu :

1. Pemungutan untuk pengambilan bahan mineral bukan logam dan batuan tidak dapat diborongkan.

2. Pendataan dan pendaftaran. Setiap pengusaha wajib Pajak Mineral bukan Logam dan Batuan yang ada di Kabupaten Pulau Morotai hendaknya mendaftarkan usahanya kepada Badan Pengelolaan Keuangan Dan Aset Daerah (BPKAD), selambat-lambatnya 1 (satu) bulan.

3. Penetapan dan perhitungan besaran pajak mineral bukan logam dan batuan. Wajib pajak mineral bukan logam dan batuan yang telah dikukuhkan diberi wewenang untuk menghitung, memperhitungkan dan menyetorkan pajak terutangnya sendiri. Besaran pajak yang terutang dihitung dengan cara mengalihkan tarif sebesar 10\% dengan DPP.

4. Penerbitan SKPD. Hasil perhitungan yang telah dilakukan oleh wajib pajak dimasukan ke BPKAD untuk dikeluarkannya Surat Ketetapan Pajak Daerah (SKPD) sebagai dasar untuk pembayaran pajak mineral bukan logam dan batuan yang terutang.

5. Pembayaran pajak. Wajib pajak yang telah menerima SKPD kemudian membayarkan pajak terutangnya pada Bank Maluku selaku bank yang ditunjuk oleh bupati. Wajib pajak kemudian menerima bukti pembayaran atau slip pembayaran yang dikeluarkan oleh bank.

6. Pelaporan. Bukti penerimaan yang diterima dari bank dilampirkan kembali dengan Surat Setoran Pajak Daerah (SSPD) dan dilaporkan ke BPKAD untuk divalidasi sehingga wajib pajak dapat memperoleh Surat Pencairan Dana yang akan dikeluarkan oleh Kepala Badan Pengelolaan Keuangan Dan Aset Daerah. 
Sistem dan Prosedur Pembayaran dan Penagihan Pajak Mineral Bukan Logamdan Batuan. Sebelum melakukan pembayaran pajak, wajib pajak memperhitungkan terlebih dahulu besaran pajak yang terutang. Perhitungan dilakukan dengan mengalikan tarif pajak dengan Dasar Pengenaan Pajak (DPP). Besaran tarif pajak dan batuan pada BPKAD disesuaikan dengan Keputusan Bupati Pulau Morotai Nomor 970/115/PM/2018 tentang Penetapan Harga Patokan Penjualan Mineral Bukan Logam Dan Batuan dengan tarif pajak mineral bukan logam dan batuan sebesar $10 \%$. Tata cara pemungutannya sebagai berikut:

1. Pembayaran pajak dilakukan di bank yang telah ditunjuk oleh bupati Kabupaten Pulau Morotai yaitu Bank Maluku.

2. Pembayaran pajak menggunakan Surat Ketetapan Pajak Daerah (SKPD) yang dikeluarkan oleh BPKAD Kabupaten Pulau Morotai yang menjelaskan berapa besar pajak terutang yang harus dibayarkan sebagai dasar penetapan pajak.

3. Setelah melakukan pembayaran, wajib pajak menerima bukti pembayaran atau slip pembayaran dari bank dan juga Surat Setoran Pajak Daerah (SSPD).

4. Pembayaran pajak mineral bukan logam dan batuan yang terutang dapat diangsur dalam kurun waktu tertentu sesuai dengan persetujuan bupati.

5. Pembayaran Pajak Paling lambat 30 hari setelah SKPD diterima oleh wajib pajak atau tanggal jatuh tempo.

6. Bila lewat dari 30 hari dan pajak mineral bukan dan batuan yang terutang tidak/kurang dibayar, maka akan dikenakan denda berupa bunga sebesar $2 \%$ per bulan.

Berikut adalah dasar pengenaan pajak untuk pengambilan mineral bukan logam dan batuan:

Tabel 1. Dasar Pengenaan Pajak

\begin{tabular}{llrrrrr}
\hline \multirow{2}{*}{ No } & Lokasi / Kecamatan & Batu Kepala Rp/ & \multicolumn{3}{c}{ Batu Belah Rp/ } & M3 (dalam rupiah) \\
\cline { 4 - 6 } & & & $\mathbf{1 - 2 c m}$ & $\mathbf{2 - 3} \mathbf{~ c m}$ & $\mathbf{5 - 7} \mathbf{~ c m}$ & $\mathbf{1 5 - 2 0} \mathbf{~ c m}$ \\
\hline 1. & Morotai Selatan & 30.000 & 25.000 & 25.000 & 25.000 & 25.000 \\
2. & Morotai Utara & 37.290 & 37.290 & 37.290 & 37.290 & 37.290 \\
3. & Morotai Timur & 37.290 & 37.290 & 37.290 & 37.290 & 37.290 \\
4. & Morotai Selatan Barat & 39.550 & 39.550 & 39.550 & 39.550 & 39.550 \\
5. & Morotai Jaya & 39.550 & 39.550 & 39.550 & 39.550 & 39.550 \\
\hline
\end{tabular}

Sumber: BPKAD Kabupaten Pulau Morotai, 2018

Tabel 2. Dasar|Pengenaan Pajak

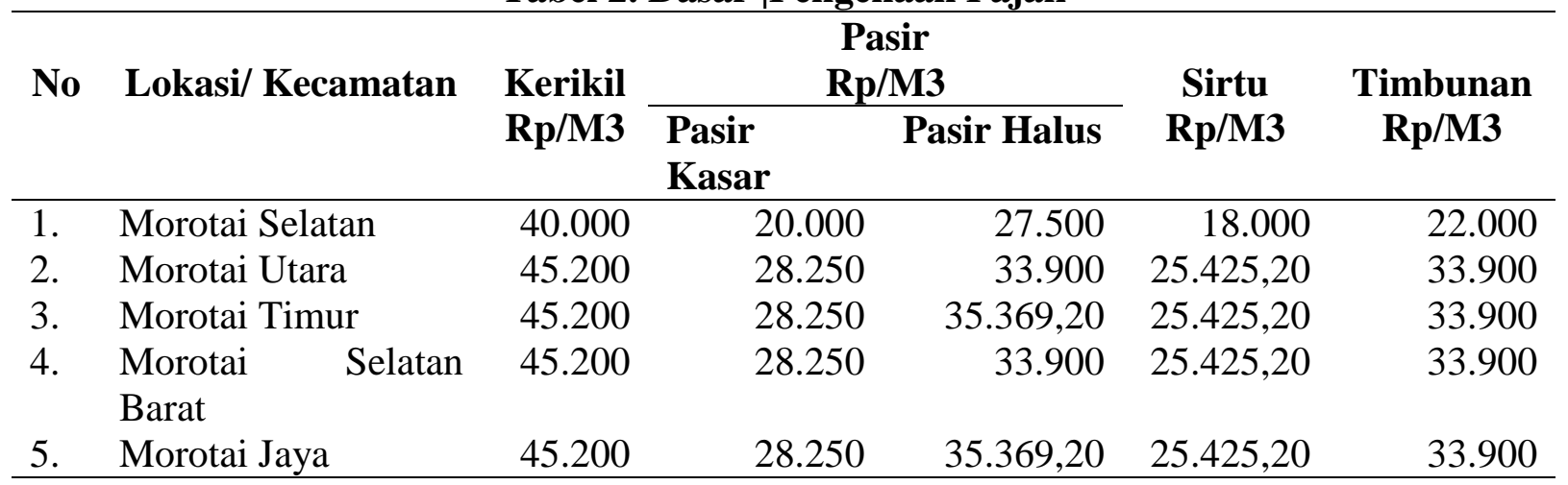

Sumber : BPKAD Kabupaten Pulau Morotai, 2018

Sistem Pencatatan dan Pelaporan Pajak Mineral Bukan Logam dan batuan. Badan Pengelolaan Keuangan dan Aset Daerah khususnya bidang penerimaan pajak daerah mencatat penyetoran pajak mineral bukan logam dan batuan yang terutang tersebut di kas daerah sebagai penerimaan pajak mineral bukan logam dan batuan sebesar pajak yang telah dibayarkan tersebut. Pencatatan tersebut dilakukan di buku penerimaan pajak daerah, 
sedangkan pencatatan lain juga dilakukan oleh bidang akuntansi dengan menjurnal penerimaan pajak berdasarkan SKPD yang dikeluarkan. Misalnya CV Morotai Perkasa sebagai wajib pajak mineral bukan logam dan Batuan telah menghitung dan membayarkan pajak mineral bukan logam dan batuan yang terutang berdasarkan SKPD untuk pembangunan ruang kelas sebesar RP. 3.497.181,63 maka ayat jurnal yang akan muncul yaitu:

1. Pada saat BPKAD belum menerima pembayaran pajak mineral bukan logam dan batuan.

Piutang Pajak Mineral Bukan Logam Dan Batuan Rp. 3.497.181,63

Pajak Mineral Bukan Logam Dan Batuan

Rp. 3.497.181,63

2. Pada saat penerimaan

Kas Daerah Rp. 3.497.181,63

Penerimaan pajak mineral bukan logam dan batuan Rp. 3.497.181,63

Setelah pencatatan di buku penerimaan pajak daerah, penerimaan pajak mineral bukan logam dan batuan juga diinput langsung kedalam Sistem Informasi Managemen Daerah (SIMDA). Pada Badan Pengelolaan Mineral Bukan Logam dan Batuan setelah dilakukannya pemungutan kemudian wajib pajak membayaran pajak terutangnya dapat melaporkannya ke BPKAD dengan menggunakan lampiran SKPD dan SSPD untuk melakukan validasi. Bukti pembayaran yang diterima oleh wajib pajak terdiri dari 5 rangkap yaitu: 1 rangkap untuk wajib pajak; 2 rangkap untuk bank' dan sisanya digunakan sebagai tembusan untuk bendaara penerimaan dan bagian BUD. Sedangkan untuk BPKAD sendiri, bendahara penerimaan akan melaporkannya sebagai penerimaan pajak mineral bukan logam dan batuan yang berdampak langsung pada peningkatan pendapatan asli daerah.

\subsection{Pembahasan}

Analisis Sistem dan Prosedur Pemungutan Pajak Mineral Bukan Logam dan Batuan Pada BPKAD Kabupaten Pulau Morotai

1. Analisis Kepatuhan Pemungutan Pajak Mineral Bukan Logam dan Batuan. Jika dilihat dari system pemungutan dan tata cara pemungutan yang diterapkan oleh BPKAD Kabupaten Pulau Morotai sudah sesuai deng Undang-Undang No. 28 tahun 2009 tentang Pajak Daerah dan Retribusi daerah serta Pertauran Pemerintah No 55 Tahun 2016 tentang Tata Cara Pemungutan Pajak Daerah. Selanjutnya jika dilihat dari objek pemungutan yang telah disebutkan pada bagian sebelumnya terdapat kurangnya objek pemungutan di Kabupaten Pulau Morotai. Ada 38 jenis mineral bukan logam dan batuan yang menjadi objek pemungutan pajak mineral bukan logam dan batuan berdasarkan Undang-Undang No 28 tahun 2009, sedangkan yang dipungut di BPKAD Kabupaten Pulau Morotai hanya ada 6 jenis saja. Hal ini dikarenakan hanya ada 6 jenis bahan mineral bukan logam dan batuan yang ada dan menjadi objek pemungutan pajak mineral bukan logam dan batuan di Kabupaten Pulau Morotai. Badan Pengelolaan Keuangan dan Aset daerah juga masih belum menggunakan SOP yang baku untuk penerimaan pajak daerah baik pemungutan maupun penagihannya.

2. Analisis Pengendalian Internal Sistem dan Prosedur Pemungutan Pajak Mineral Bukan Logam dan Batuan. Pendekatan yang digunakan dalam menganalisi pengendalian internal sistem dan prosedur pemungutan pajak mineral bukan logam dan batuan yaitu pendekatan analisis COSO. Dilihat dari 5 aspek yaitu :

1. Lingkungan Pengendalian; untuk lingkungan pengendalian sistem dan prosedur pemungutan sudah memadai yaitu dilakukan sudah sesuai denga peraturan yang ada namun kelemahannya di BPKAD Kabupaten Pulau Morotai Masih belum mempunyai SOP yang baku.

2. Penilaian Resiko; penilaian resiko untuk pemungutan pajak dilihat sudah memadai dengan penetapan strategi-strategi serta tujuan yang dilakukan oleh BPKAD sehingga 
pemungutan dapat lebih efektif dan tidak menimbulkan resiko dimasa yang akan datang.

3. Kegiatan Pengendalian untuk pemungutan pajak mineral bukan logam dan batuan yang dilakukan oleh BPKAD yaitu dengan melakukan review kinerja pegawai.

4. Informasi dan Komunikasi yang dilakukan oleh BPKAD dapat dikatakan sudah memadai dengan penyampaian informasi dan komunikasi yang baik yang dilakukan oleh BPKAD dari pendaftaran sampai pada pelaporannya.

5. Kegiatan pemantauan; kegiatan pematauan yang dilakukan oleh BPKAD berupa pemantauan langsung prosedur pemungutan yang diawasi langsung oleh Kepala BPKAD dan Kepala Bidang Pendapatan dan Pajak.

Analisis Pembayaran dan Penagihan Pajak Mineral Bukan Logamdan Batuan Pada Kabupaten Pulau Morotai

1. Analisis Kepatuhan. Berdasarkan hasil penelitian pada bagian sebelumnya, tata cara pembayaran pajak mineral bukan logam dan batuan sudah dilaksanakan atau dijalankan sesuai dengan PERDA Kabupaten Pulau Morotai Nomor 08 tahun 2011 tentang Pajak Mineral Bukan Logam Dan Batuan yaitu pembayaran dilakukan di Bank Maluku sebagai bank yang ditunjuk oleh Bupati. Tarif yang dikenakan oleh BPKAD Kabupaten Pulau Morotai jika dilihat dengan tarif pajak yang ditetapkan berdasarkan Undang-Undang Nomor 28 Tahun 2009 tentang Pajak Daerah dan Retribusi Daerah dapat dikatakan tidak sama. Tarif pajak mineral bukan logam dan batuan menurut Undang-Undang Nomor 28 Tahun 2009 tentang Pajak Daerah dan Retribusi Daerah yaitu sebesar 25\% namun tarif yang ada di BPKAD Kabupaten Pulau Morotai sebesar 10\% dengan menggunakan Keputusan Bupati Pulau Morotai Nomor 970/115/PM/2018 yang mulai berlaku per 1 januari 2018, perubahan tarif ini dilakukan oleh berbagai pertimbangan yang ada. Perbedaan tarif tersebut tidak menjadi masalah, hal ini dikarenakan untuk penetuan tarif pajak daerah menggunakan Official Assesment System yang dimana penentuan tarif pajak daerah ditentukan oleh Bupati dengan persetujuan DPRD. Dalam penagihannya juga BPKAD melakukannya berpatokan pada PERDA Kabupaten Pulau Morotai Nomor 08 Tahun 2011 tentang Pajak Mineral Bukan Logam dan Batuan.

2. Analisis Pengendalian Internal Pembayaran dan Penagihan Pajak Mineral Bukan

Logamdan Batuan. Pengendalian internal pembayaran dan penagihan pajak yang dilakukan oleh BPKAD Kabupaten Pulau Morotai yaitu sebagai berikut:

1. Lingkungan pengendalian untuk pembayaran dan penagihan pajak yang diterapkan oleh BPKAD dapat dilihat dengan adanya prosedur atau tata cara pembayaran uyang dilaksanakan sesuai dengan PERDA Kabupaten Pulau Morotai No. 08 tahun 2011.

2. Penilaian risiko yang dilakukan oleh BPKAD yaitu dengan menganalisis lingkungan pengambilan mineral bukan logam dan batuan sehingga dapat mengetahui potensi yang dimiliki guna meminimalisir risiko yang akan terjadi.

3. Aktivitas pengendalian pembayaran pajak mineral bukan logam dan batuan dilakukan oleh BPKAD dengan mengevaluasi mengenai penerimaan pajak dalam satu tahun dan membandingkan dengan tahun sebelmnya untuk mengetahui apakah ada peningkatan atau tidak.

4. Informasi dan Komuniikasi untuk pembayaran dan penagihan pajak dilakukan melalui sistem bank serta penyampaian informasi bagi WP sudah lebih terbuka.

5. Aktivitas pemantauan pembayaran dan penagihan pajak yang dilakukan oleh BPKAD dipantau langsung oleh Kepala BPKAD dan Kepala Bidang Pendapatan dan Pajak.

Analisis Sistem Pencatatan dan Pelaporan Pajak Mineral Bukan Logam dan Batuan Pada Kabupaten Pulau Morotai

1. Analisis Kepatuhan. BPKAD Kabupaten Pulau Morotai melakukan pencatatan dengan dua cara yaitu sebagai berikut: 
1. Pertama pencatatannya akan dilakukan secara manual yaitu bendahara penerimaan akan mencatat pelunasan pajak mineral bukan logam dan batuan kedalam buku penerimaan kas daerah dan bagian akuntansi akan mencatat ayat jurnalnya sebagai kas daerah terhadap piutang pajak sebesar pajak yang telah dibayarkan oleh wajib pajak.

2. Kedua, pencatatan yang diberlakukan pada BPKAD menggunakan Sistem Menejemen Daerah (SIMDA) hal ini sangat membantu dalam melihat kesesuaian mulai dari pendaftaran, pemungutan sampai pada penerimaan pajaknya.

Dengan penggunaan SIMDA sebagai sistem yang membantu pengelelolaan keuangan daerah berarti BPKAD sudah menjalankan Peraturan Pemerintah No 56 Tahun 2005 tentang Sistem Informasi Keuangan Daerah. Untuk pelaporan pajak wajib pajak melaporkan pembayarannya ke BPKAD dengan melampirkan SKPD beserta bukti pembayaran(slip bank) atau SSPD ke Bendahara penerimaan dan bagian BUD sehingga divalidasi dan dapat diproses untuk pencairan dananya. Sedangkan Bendahara penerimaan akan melaporkannya menjadi pedapatan pajak mineral bukan logam dan batuan yang masuk ke kas daerah dan berdampak pada peningkatan PAD.

2. Analisis Pengendalian Internal Sistem Pencatatan dan Pelaporan Pajak Mineral Bukan Logam dan Batuan. Pengendalian internal pencatatan dan pelaporan yang dilakukan oleh BPKAD Kabuapten Pulau Morotai sebagai berikut:

1. Lingkungan Pengendalian: sistem dan prosedur pencatatan dan pelaporan yang dilakukan oleh BPKAD dilihat sangat baik dan terarah sesuai denga prosedur yang ada ,mulai dari pendaftaran WP sampai penerimaannya oleh setiap bidang.

2. Penilaian Risiko: penilaian risiko yang dilakukan oleh BPKAD untuk pencatatan dan pelaporan pajak yaitu dengan membuat laporan penerimaan yang menjadi patokan untuk tahun berikutnya.

3. Aktivitas Pengendalian: aktivitas pengendalian yang diterapkan oleh BPKAD untuk pencatatan dan pelaporan yaitu evaluasi kinerja pegawai dan membandingkannya dengan tolak ukur yang ada.

4. Informasi dan komunikasi: dalam pencatatan dan pelaporan pajak di BPKAD sudah memadai dengan menggunakan SIMDA sehingga penerimaan maupun penyampaian informasinya sudah lebih baik.

5. Aktivitas pemantauan: sama halnya dengan prosedur pemungutan serta pembayaran, prosedur pencatatan dan pelaporan juga diawasi langsung oleh kepala BPKAD dan kepala bidang pendapatan dan paj sehingga lebih efektif.

\section{KESIMPULAN DAN SARAN}

\subsection{Kesimpulan}

Berdasarkan pembahasan yang telah diuraikan sebelumnya, maka kesimpulan penelitian adalah sebagai berikut:

1. Sistem dan tata cara pemungutan pajak mineral bukan logam dan batuan pada Badan Pengelolaan Keuangan dan Aset Daerah Kabupaten Pulau Morotai Kabupaten Pulau Morotai Sudah sesusai dengan Undang-Undang No 28 Tahun 2009 dan Peraturan Pemerintan No 55 Tahun 2016. Hanya saja untu BPKAD sendiri belum menggunakan SOP yang baku dalam pemungutan pajak daerah.

2. Sistem pembayaran dan penagihan yang diterapkan pada Badan Pengelolaan Keuangan dan Aset Daerah Kabupaten Pulau Morotai sudah sesuai dengan Undang-Undang No 28 Tahun 2009.

3. Sistem pencatatan dan pelaporan pajak mineral bukan logam dan batuan pada BPKAD Kabupaten Pulau Morotai telah dijalankan dan dilaksanakan sesuai dengan Peraturan 
Pemerintah No 56 Tahun 2005 tentang Sistem Informasi Keuangan Daerah dan UndangUndang No 28 Tahun 2009.

4. Pengendalian internal COSO untuk sistem dan prosedur pemungutan, pembayaran, penvcatatan serta pelaporan yang dilakukan oleh Badan Pengelolaan Keuangan Dan Aset daerah dilihat dari komponen-komponen sebagai berikut: lingkungan Pengendalian yang sudah memadai, penilaian resiko yang masih perlu ditingkatkan, kegiatan pengendalian yang sudah memadai, informasi dan komunikasi yang sudah memadai, dan pemantauan yang sudah memadai

\subsection{Saran}

Saran yang dapat penulis berikan untuk BPKAD Kabupaten Pulau Morotai sejalan dengan uraian pembahasan yakni:

1. Sistem dan tata cara pemungutan yang ada di BPKAD Kabupaten Pulau Morotai harus dilihat kembali agar lebih baik lagi yaitu dengan pembuatan SOP Pemungutan maupun SOP Penerimaan pajak yang baku sehingg dapat menjadi dasar dalam pelaksanaan kegiatan yang ada.

2. Keseluruhan pengendalian internal melalui analisis COSO dilihat sudahmemadai hanya saja pada komponen penilaian risiko BPKAD harus lebih meningkatkan lagi agar system pengendalian interen dapat lebih baik lagi.

3. Untuk pengawasan pajak mineral bukan logam dan batuan lebih ditingkatkan agar penerimaan pajak mineral bukan logam dan batuan dapat memberikan hasil yang lebih baik.

\section{DAFTAR PUSTAKA}

Harahap, Sofyan Syafri. 2013. Teori Akuntansi. Bumi Aksara. Jakarta. Mardiasmo. 2016. Perpajakan. Andi. Yogyakarta

Muljono, Djoko. 2018. Akuntansi Perpajakn. Andi. Yogyakarta.

Peraturan Pemerintah No 55 Tahun 2016 Tata Cara Pemungutan Pajak Daerah. 2016. Jakarta

Resmi, Siti. 2012. Perpajakan Teori dan Kasus. Salemba Empat. Jakarta

Sidik, Hartowo. 2016. Sistem Pemungutan Pajak Mineral Bukan Logam dan Batuan (MINERBA) Pada Dinas Pendapatan Daerah Kabupaten Sekadau. Skripsi. Universitas Tanjungpura. Pontianak

Siahaan, Marihot P. 2016. Pajak Daerah dan Retibusi Daerah. Jakarta Rajawali Perss. Jakarta.

Tampubolon, Karianto. 2016. Akuntansi Perpajakan dan Cara Menghadapi Pemeriksaan. Indeks. Jakarta.

Tesalonika, Moningka. 2016. Analisis Potensi dan Efektivitas Penerimaan dan Pemungutan Pajak Mineral Bukan Logam dan Batuan Sebagai Sumber Pendapatan Asli Daerah (PAD) di Kabupaten Minahasa Utara. Jurnal Riset Akuntansi Kelangsungan Hidup 11(3).

Undang-Undang Republik Indonesia Nomor 53 Tahun 2008 Pembentukan Kabupaten Pulau Morotai Di Provinsi Maluku utara. 2008. Lembaran Negera Indonesia Tahun 2008. Jakarta.

Undang-Undang Republik Indonesia Nomor 28 Tahun 2009 Ketentuan UmumPerpajakan. 2009. Lembaran Negera Indonesia Tahun 2009. Jakarta.

Undang-Undang Republik Indonesia Nomor 32 Tahun 2004 tentang Daerah-Daerah yang Bersifat Otonom atau Bersifat Administrasi. Lembaran Negera Indonesia Tahun 2004. Jakarta 